\title{
Comparative efficacy analysis of anti-microbial peptides, LL-37 and indolicidin upon conjugation with CNT, in human monocytes
}

Biswaranjan Pradhan, Dipanjan Guha, Krushna Chandra Murmu, Abhinav Sur, Pratikshya Ray, Debashmita Das and Palok Aich ${ }^{*}$ (I)

\begin{abstract}
Background: Antimicrobial peptides (AMPs) have the potential to serve as an alternative to antibiotic. AMPs usually exert bactericidal activity via direct killing of microbial pathogens. Reports have proposed that by harnessing innate immune activation, AMPs can regulate pathogen invasion and may control infection. It has been reported that AMPs could be utilized to activate the innate mucosal immune response in order to eliminate pathogenic infections. This way of controlling pathogen infection, by activating host immunity, confers the potential to the select AMPs to alleviate the problem of antibiotic resistance. Among various AMPs tested LL-37 and indolicidin, showed promise to be potential candidates for eliciting enhanced host innate immune responses. LL-37 and indolicidin had exhibited substantial innate immune activation in both human and murine macrophages. Dosage for each of the AMPs, however, was high with adverse side effects.
\end{abstract}

Results: In this study, we reported that upon conjugation with carbon nanotubes (CNT), each AMP remained biologically functional at a concentration that was 1000 -fold less than the dosage required for free AMP to remain active in the cells.

Conclusions: Current study also revealed that while indolicidin induced signalling events mediated through the TNFRSF1A pathway in THP1 cells, followed by activation of NFKB and c-JUN pathways, treatment of cells with LL-37 induced signalling events by activating IL1R, with subsequent activation of NFKB and NFAT2. Thp 1 cells, primed with CNT conjugated LL-37 or indolicidin, are protected against Salmonella typhimurium infection at $16 \mathrm{~h}$ post challenge.

Keywords: Carbon nanotube, Antimicrobial peptides, Cationic peptides, Host defense peptides, Innate immunity

\section{Background}

The antimicrobial activity of cationic peptides is mostly elicited via direct interaction with microbes $[1,2]$. However, direct attack on microbes to attain anti-microbial effects is not a good strategy because microbes tend to develop resistance against antimicrobial agents over time. An alternative paradigm for prophylactic or therapeutic

\footnotetext{
${ }^{*}$ Correspondence: palok.aich@niser.ac.in

School of Biological Sciences, National Institute of Science Education and Research (NISER), HBNI, P.O. Bhimpur-Padanpur, Khurdha, Jatni, Odisha 752050, India
}

success would involve activating the innate immune system of the host through treatment with a sub optimal dosage of antimicrobial agents, rather than a direct attack on the microbes. This methodology could alleviate the possibility of microbes developing a resistance against antimicrobial agents. Keeping this logic in mind, we have compared the antimicrobial activities of two therapeutically potential antimicrobial peptides (AMPs), with potential and proven medicinal properties, LL-37 and indolicidin, in vitro.

LL-37 is a proven and potent AMP. LL-37 is of human origin [3]. LL-37 was first detected in leukocytes and in 
the testis of humans [4]. Subsequently, it was also found inside a large variety of cells, tissues and body fluids. LL-37 was initially recognized for its antimicrobial properties [5-7] against bacteria, fungi and viral pathogens [8, 9]. LL-37 neutralizes lipopolysaccharides $[10,11]$ because of its high affinity towards LPS [10]. LL-37 also plays a significant role in wound healing, angiogenesis and apoptosis [12]. Most importantly, recent studies suggest that it is also involved in the regulation of cancer [13].

Indolicidin, the other AMP used in the current study, belongs to the cathelicidin class of AMPs. Indolicidin purified from the cytoplasmic granules of bovine neutrophils. Indolicidin is capable of killing gram-negative bacteria by crossing the outer membrane and causing disruption of the cytoplasmic membrane by channel formation [14]. Indolicidin is also active against grampositive bacteria, fungi, protozoa and enveloped viruses such as HIV-1 $[15,16]$. Apart from direct neutralization of microbes, another important function of indolicidin is its ability to modulate the host innate immune system against infectious agents $[17,18]$. Indolicidin exerts many immunomodulatory roles, including-but not limited to-chemotaxis, modulation of cytokine and chemokine expression, and leukocyte activation [19, 20]. Instead of utilizing the direct antimicrobial effects of indolicidin, its immunomodulatory properties could be exploited to facilitate pathogen clearance in the host. Interestingly, the concentration of indolicidin required to stimulate the innate immune system is comparable to its antimicrobial concentration of $10-20 \mu \mathrm{g} / \mathrm{ml}$. This equivalence of concentration, for innate mucosal immunity activation and for antimicrobial activity, is a major concern to develop antimicrobial resistance. It is, therefore, urgently required to have a methodology to reduce the dosage required to modulate host innate immunity.

Both natural and synthetic AMPs have shown promise as 'next generation antibiotics' due to their unique mode of membranolytic action, which minimizes the development of microbial resistance. However, bacteria have evolved the following mechanisms to counteract AMPs: (i) by a transient induction of bacterial signalling systems that help the bacteria to cope with AMPs, and (ii) constitutive resistance as a result of genetic changes. Currently, there are several putative mechanisms known for bacterial resistance to AMPs [2, 21-24]. When AMPs are present at higher concentrations, bacteria modulate their cell surface by making it less negatively charged and less permeable [25-27].

Despite the apparent medical potential of AMPs, their activity is not clinically practical because of weak activity, nonspecific cytotoxicity and proteolytic effect on some host membrane proteins [28]. For example, indolicidin is cytotoxic for rat and human T-lymphocytes [29]. Also, in vivo studies have confirmed that indolicidin is toxic to erythrocytes [15] at a high concentration $(10 \mu \mathrm{g} / \mathrm{ml})$. Indolicidin's immune modulatory efficacy with respect to concentration needs to be increased in order to avoid damage to the host and development of indolicidin resistance in bacteria. Previous studies have demonstrated that immune modulatory efficacy as well as delivery of $\mathrm{CpG}$ is enhanced when conjugated with nanoparticles [30-32]. Additionally, we have recently reported that conjugation of indolicidin with short multi-walled carbon nano-tubes (SM-CNT) enhanced the efficacy of indolicidin by increasing its ability to protect host cells from Salmonella typhimurium serovar enterica (ST) MTCC 3232 challenge [1].

In the present study, we have demonstrated that the comparative efficacy and in vitro functioning of LL-37 and indolicidin conjugated with SM-CNTs. We have studied the effects of free and nano-conjugated indolicidin treatment on the human monocyte cell line THP-1 through transcriptomics. We have also selected LL-37 for our current study as it has already been tested for various immune modulatory effects [33]. Our results revealed that following conjugation of LL-37 and indolicidin with SM-CNTs, the immune modulatory efficacy of LL-37 and indolicidin was significantly increased in vitro. Our results revealed that an effective level of activity for the peptides is maintained following CNT-conjugation even at a 1000 -fold less dosage than free peptide.

\section{Methods}

\section{Synthesis of CNT-indolicidin and CNT-LL-37}

LL-37 was obtained from Prof. Bob Hancock, UBC, Canada as a gift and indolicidin was purchased from BR Biochem Lifesciences, India. Both AMPs were obtained as lyophilized powder. LL-37 and indolicidin were conjugated with CNT using EDC-NHS conjugation protocol as described elsewhere [34], which was described in our previous work reported with indolicidin [1]. LL-37 was conjugated using the same protocol $5 \mathrm{mg}$ of LL-37 was suspended in $25 \mu \mathrm{l}$ of DMSO. The resulting solution was mixed properly followed by further addition of $975 \mu \mathrm{l}$ of PBS to make a $5 \mathrm{mg} / \mathrm{ml}$ peptide solution. This solution was used as the stock peptide solution for our experiment. $400 \mu \mathrm{l}$ of the $1 \mathrm{mg} / \mathrm{ml} \mathrm{CNT}$ solution, prepared earlier was put in a clean and sterile microfuge tube. To the above solution, $600 \mu \mathrm{l}$ of MES buffer $(\mathrm{pH}=5.0)$ used as the appropriate activation buffer was added. This is because activation of the carboxyl groups on the nanotubes using EDC and NHS is most efficient at $\mathrm{pH}=4.5-$ 7.2. $5 \mu \mathrm{l}$ of $0.4 \mathrm{M} \mathrm{EDC}$ and $50 \mu \mathrm{l}$ of $0.1 \mathrm{M} \mathrm{NHS}$ was added respectively and the solution was incubated in dark for $45 \mathrm{~min}$ at room temperature. Once the activation reaction is complete, $1.4 \mu \mathrm{l}$ of 2-mercaptoethanol was added to quench the effect of EDC. $960 \mu \mathrm{l}$ of $\mathrm{PB}(\mathrm{pH}=7.2)$ was 
added to $1 \mathrm{ml}$ of the activated solution. The solution was mixed by gentle pipetting. PBS is used as the conjugation buffer. Therefore, after adding $40 \mu \mathrm{l}$ of the stock $5 \mathrm{mg} / \mathrm{ml}$ peptide solution, the resulting solution was mixed thoroughly and incubated in dark for $2 \mathrm{~h}$ at room temperature. In addition, free LL-37 was diluted to the similar extent for proper comparison to the conjugates. Spike was prepared by adding same concentrations of LL-37 to a solution of non-activated CNTs. Free peptides were removed from the conjugate mixture using molecular weight cut-off spin columns (3 MWCO, Millipore, USA). Short multiwalled CNTs were purchased from Cheap tubes with outer diameter $8 \mathrm{~nm}$ and inner diameter of 2-5 $\mathrm{nm}$ and length between 500 and $2000 \mathrm{~nm}$. Molecular weight of CNTs were calculated based on protocols mentioned before and on the homepage of Hipco [35, 36] assuming standard $0.14 \mathrm{~nm}$ of distance between $\mathrm{C}-\mathrm{C}$ covalent bonds for the circumference and a hexagonal pack distance of $0.283 \mathrm{~nm}$ for weak long range interactions. Using these parameters and the value of total surface area as provided by the manufacturer, the average molecular weight determined was $2 \times 10^{6}$. Stock concentration of CNT calculated was $50 \mu \mathrm{M}$.

\section{Physical characterization through Fourier transformed infrared (FTIR) spectroscopy}

FTIR spectrum of free and conjugated AMPs along with positive controls was collected using Perkin Elmer FTIR model Spectrum RX1 equipment. Purified samples were lyophilized and prepared for FTIR measurement. FTIR measurements were performed at room temperature in the absorbance range from 4000 to $400 \mathrm{~cm}^{-1}$ by accumulating 20 scans with a spectral resolution of $1 \mathrm{~cm}^{-1}$. The data was normalized against potassium bromide spectrum, obtained from the same instrument under the same instrumental settings.

\section{Physical characterization through isothermal calorimetry} Isothermal calorimetry (GE Healthcare MicroCalTMiTC200) was used to investigate the potentiality of peptides to interact with free activated nanoparticles. $1 \mu \mathrm{l}$ sample was injected at each time point (injection time $5 \mathrm{~s}$ ) with a gap of $300 \mathrm{~s}$ between each injection, 40 such injections were carried out. The baseline setting was at $10 \mu \mathrm{cal}$. To get a steady baseline, a $2000 \mathrm{~s}$ delay was applied to the system. The resulting thermodynamic parameters related to the binding of the peptide to the carboxyl groups on the nanomaterials were obtained from the signal.

\section{Physical characterization through UV-Visible spectroscopy and isothermal calorimetry (ITC)}

UV-Vis spectrophotometry was conducted using NanoDrop 2000 (Thermo-Scientific, USA) in the wavelength range of 200-550 $\mathrm{nm}$. Concentration of peptide was evaluated spectrophotometrically and the stoichiometry of peptide-CNT conjugation was determined by Scatchard plot [1]. Thermodynamic parameters such as changes in free energy, enthalpy and entropy of peptide and CNT binding was determined by titrating the activated CNTs by the peptide using ITC as described before [1].

\section{Physical characterization through binding isotherm}

Following activation of the carboxyl groups on free CNTs, carboxylated CNTs were titrated against increasing concentrations of the peptide. Change in absorbance at $260 \mathrm{~nm}$ was monitored till saturation of binding was observed. Concentration of CNT used was $5 \mu \mathrm{M}$ for the titration. Binding isotherm for CNT-LL37 conjugation was determined using Scatchard plot to obtain the association constant and the stoichiometry of binding as described elsewhere for binding of CNT and indolicidin [1]. In addition, free non-activated nanoparticles were also titrated against increasing concentrations of LL-37 to ensure specificity of binding. Dissociation binding constant $\left(\mathrm{K}_{\mathrm{d}}\right)$ and Stoichiometry $\left(\mathrm{B}_{\max }\right)$ was determined using one, two and multiple site binding isotherm models [37]. All analyses were done using GraphPad Prism 5.01 software, CA, USA.

\section{Peptide and CNT conjugated peptide uptake assay through confocal microscopy}

Peptide was labeled with Cy3 (GE HealthScience, USA). Cells were treated with free and conjugated labeled peptide at a concentration of $0.02 \mu \mathrm{g} / \mathrm{ml}$ in terms of peptide for $2 \mathrm{~h}$ following fixing of the cells with $2 \%$ paraformaldehyde. DAPI (Himedia, India) and cell mask red (Invitrogen, USA) were for nuclear and cell membrane staining. Cells were then mounted using fluoromount G (Southern Biotech, USA) and images were taken by a LSM confocal microscope (Carl Zeiss LSM 780, Germany).

\section{Animal cell culture}

The Raw 264.7 murine macrophage and THP-1 human primary monocyte cell lines were obtained from ATCC (Manassas, VA). RPMI-1640 (Himedia, India) supplemented with $4.5 \mathrm{~g} / \mathrm{l} \mathrm{D}$-glucose, $25 \mathrm{mM}$ HEPES, $0.11 \mathrm{~g} / \mathrm{l}$ sodium pyruvate, $1.5 \mathrm{~g} / \mathrm{l}$ sodium bicarbonate, $2 \mathrm{mM}$ L-glutamine and 10\% FBS along with 100 units $/ \mathrm{ml}$ Gentamycin and $100 \mathrm{pg} / \mathrm{ml}$ Amphotericin-B was used to maintain both the cell lines. PMA (phorbol-12-myristate13-acetate) of $100 \mathrm{nM}$ was used for THP-1 cell differentiation into adherent macrophages. Both cell lines were routinely cultured in our laboratory at $37^{\circ} \mathrm{C}$ in a humidified atmosphere containing $5 \% \mathrm{CO}_{2}$. The cells were subcultured twice a week to maintain an exponential growth state. 


\section{Cell treatment}

One million macrophage cells per well in $2 \mathrm{ml}$ cell culture media were grown in 6 well plates overnight. Free AMP was administered to the cells at a final concentration of either 0.02 or $20 \mu \mathrm{g} / \mathrm{ml}$. CNT conjugated AMPs were used at $0.02 \mu \mathrm{g} / \mathrm{ml}$ to treat the cells. Control treatment used free CNT and CNT spiked with AMP. Following treatment, the cells were incubated for $6 \mathrm{~h}$ in a $\mathrm{CO}_{2}$ incubator. Following $6 \mathrm{~h}$ of incubation, culture medium was aspirated off and the cells were washed 3 times with PBS. Cells were trypsinized and suspended in cell culture medium and centrifuged at approximately $300 \mathrm{~g}$ for $5 \mathrm{~min}$ at $37^{\circ} \mathrm{C}$. The cell pellet was collected to execute further experiments.

\section{RNA isolation}

Total RNA was extracted from treated and un-treated THP-1 cells using RNeasy mini kit (Qiagen \#74106, Germany) following manufacturers protocol. In brief, cells were gently lysed with $350 \mu$ l RLT buffer by gentle pipetting and then equal volume of $70 \%$ ethanol was added to the lysate, mixed by pipetting and passed through RNeasy mini column, which retains the RNA in its silica matrix. The column was then washed once with $750 \mu \mathrm{l}$ RW1 buffer and twice with $500 \mu \mathrm{l}$ of RPE buffer to remove unwanted lipid, protein and DNA from the matrix. RNA was then eluted from the matrix with $30 \mu \mathrm{l}$ nuclease free water and kept in ice. The concentration of extracted RNA was measured using NanoDrop 2000 instrument (Thermo Scientific, USA). RNA integrity was checked in bioanalyzer 2100 (Agilent, USA) using an RNA 6000 Nano kit (Agilent, USA) as per the manufacturer's instruction. RNA integrity number 8.5 or more was considered for downstream experiments, which included quantitative real time polymerase chain reaction (qRT-PCR) and whole genome gene expression microarray.

\section{Complementary DNA (cDNA) synthesis}

cDNA was synthesized from total RNA using reverse transcription methodology as described here briefly and detailed protocoled can be obtained from reports published before [38]. $5 \mu \mathrm{g}$ of total RNA was mixed with the buffer containing affinity script reverse transcriptase and polyT primer. The mixture was kept in the thermo cycler at $45{ }^{\circ} \mathrm{C}$ for $45 \mathrm{~min}$ to synthesize c-DNA. Next, the temperature was raised to $92{ }^{\circ} \mathrm{C}$ for $1 \mathrm{~min}$ in order to deactivate the enzyme.

\section{Quantitative real time (qRT-) PCR assay}

The qRT-PCR was performed using GoTaq qPCR Kit (Promega \#A6002, USA) using the manufacturer protocol and the expression profile of select innate immune genes in terms of fold changes for the treatments with respect to untreated samples was checked. The reaction mixture was $25 \mu \mathrm{l}$ in each well of a 96-well plate. According to the protocol, $9.4 \mu \mathrm{l}$ of $2 \times$ GoTaq qPCR Master Mix, $12.6 \mu \mathrm{l}$ of nuclease free water, $100 \mathrm{ng}$ of template cDNA and $1 \mu \mathrm{M}$ of each of forward and reverse primers (primer details are given in Additional file 1: Table S1) were added in each well. qRT-PCR amplification was performed in a programmable thermos-cycler (Stratagene 3500Mxp, USA) with the following settings: $2 \mathrm{~min}$ at $92{ }^{\circ} \mathrm{C}$ to activate DNA polymerase for 1 cycle, $15 \mathrm{~s}$ at $92{ }^{\circ} \mathrm{C}$ for melting and $1 \mathrm{~min}$ at $60{ }^{\circ} \mathrm{C}$ for primer annealing along with extension of the chain and detection of the florescence for 40 cycles. Cycle threshold $\left(C_{t}\right)$ values were noted, and fold changes of the desired genes were calculated with respect to the control after normalizing with the housekeeping gene, $\beta$-actin.

\section{Bacterial protection assay}

PMA treated $0.5 \times 10^{6}$ differentiated THP- 1 cells were seeded into each well of 12 -well plate and incubated at $37{ }^{\circ} \mathrm{C}$ for $24 \mathrm{~h}$. Cells were treated with LL-37 and indolicidin separately at a final concentration of 20 and $0.02 \mu \mathrm{g} /$ $\mathrm{ml}$; whereas conjugated peptides were administered at a lower dose of $0.02 \mu \mathrm{g} / \mathrm{ml}$. After treatment, plates were incubated for $6 \mathrm{~h}$ at $37^{\circ} \mathrm{C}$. Thereafter, THP-1 cells were challenged with $\mathrm{ST}$, a pathogenic bacterium, at a multiplicity of infection (MOI) of 10 . Cell viability counts at different time points of 6,12 and $18 \mathrm{~h}$ were determined through trypan blue dye exclusion method.

\section{Microarray and data analysis}

Genome wide gene expression study was performed using Agilent Quick-Amp labeling Kit (p/n 5190-0444 Agilent, USA). $500 \mathrm{ng}$ of each RNA samples from the control and treated cells were incubated with reverse transcription mix at $40{ }^{\circ} \mathrm{C}$ and converted to cDNA primed by oligodT with a $\mathrm{T} 7$ polymerase promoter. cDNA synthesized was used as a template for cRNA generation. cRNA was synthesized by in vitro transcription and the dyes used were Cy3 CTP (to label control sample) and Cy5 CTP (to label test samples). The cDNA synthesis and in vitro transcription steps were carried out at $40{ }^{\circ} \mathrm{C}$. Labeled cRNA was cleaned up and quality assessed for the yields and specific activity. $825 \mathrm{ng}$ each of $\mathrm{Cy} 3$ and $\mathrm{Cy} 5$ labeled samples were fragmented and hybridized to $4 \times 44 \mathrm{k}$ microarray slides. Fragmentation of labeled cRNA and hybridization were conducted using the Gene Expression Hybridization kit of Agilent (Part Number 5188-5242, Agilent, USA). Hybridization was carried out in Agilent's Surehyb Chambers at $65{ }^{\circ} \mathrm{C}$ for $17 \mathrm{~h}$. The hybridized slides were washed using Agilent Gene Expression wash buffers (Part Number 5188-5327, Agilent, USA). Slides were scanned 
using Agilent scan control software and data extraction from images was done using feature extraction software Version 10.7 (Agilent, USA). We further obtained normalized fold change values for all genes present on the microarray slides using Arraypipe (v2.0). Differentially regulated genes at various conditions were functionally clustered using WEB-based GEneSeT AnaLysis Toolkit (Webgestalt).

\section{Graphs and statistical analysis}

All graphs and statistical analysis were carried out using GraphPad Prism (V5.04, Prism, USA). Statistical analysis was performed using 2-way ANOVA to calculate levels of significance. One standard deviation was calculated and shown in the graphs.

\section{Results}

\section{Characterization of CNT conjugates}

The conjugation process and characterization for SM$\mathrm{CNT}$ and indolicidin was already reported elsewhere by the current group [1]. Similar methodologies for conjugation were utilized for LL-37 followed by biophysical characterization using UV-Vis spectroscopy, Binding isotherm, isothermal calorimetry and FT-IR spectroscopy. Conclusive characterization was achieved using FT-IR analysis. Peaks, associated with carbonyl $(\mathrm{C}=\mathrm{O})$ stretching at $1680 \mathrm{~cm}^{-1}$ and amide $(\mathrm{C}-\mathrm{N})$ bending at 1645/cm appeared in CNT-LL-37 conjugated AMPs but not in free AMPs, confirmed formation of a peptide bond between SM-CNT and LL-37 (Fig. 1d). Free AMP when spiked with SM-CNT did not result into any such peak.

Isothermal calorimetry results revealed that SMCNT and LL-37 conjugation process was exothermic with enthalpy $(\Delta \mathrm{H})$ at $-290.4 \pm 2.2 \mathrm{kcal} / \mathrm{mol}$ and free energy change $(\Delta G)-9.98 \pm 2.1 \mathrm{kcal} / \mathrm{mol}$. Free LL-37 when spiked with SM-CNT leads to enthalpy $(\Delta \mathrm{H})$ at $-62.58 \pm 2.6 \mathrm{kcal} / \mathrm{mol}$ and free energy change $(\Delta G)$ $-5.36 \pm 2.63 \mathrm{kcal} / \mathrm{mol}$ (Fig. 1a). We further established the strength and stoichiometry of binding. Fraction bound with increasing concentration of the peptides was determined by spectrophotometric titration for association of LL-37 with CNT (Fig. 1b, c). Dissociation constant $\left(\mathrm{K}_{\mathrm{d}}\right)$ for the LL-37 and CNT binding was $4.6 \mu \mathrm{M}$ with a stoichiometry of binding $\left(\mathrm{B}_{\max }\right)$ value of 1.15 results from binding isotherm analysis (Fig. 1c). The binding constants determined also corroborated with the concentrations used in the experiment. There was no significant association observed when non-activated CNT was mixed with LL-37 (spiked samples). This observation was further validated by thermodynamic parameters described above. The CNT conjugated peptide was internalised by the macrophages (Fig. 1g) whereas the free peptide was diffused all over the macrophage cell membrane (Fig. 1f).
Cell viability of THP-1 cells treated with free and conjugated LL-37 and indolicidin

Before establishing the efficacy of CNT conjugated AMPs, it is important to check viability of the cells following treatment with nano-conjugated peptides. Viability of the human macrophage cell line THP-1 and mice macrophage cell line Raw 264.7 were determined up to $6 \mathrm{~h}$ following treatment with free and CNT conjugated AMPS (LL-37 and indolicidin). Macrophage cells were viable for entire $6 \mathrm{~h}$ following treatment with free and conjugated AMPs (Fig. 2a, e). Longer than $6 \mathrm{~h}$ time point was not chosen since, (a) our goal is to prime early immune response and (b) $4 \mathrm{~h}$ was shown as sufficient to exhibit immune modulation in vitro [39]. For free AMPS highest concentration reported was $50 \mu \mathrm{g} / \mathrm{ml}$ while that for conjugated AMP was $2 \mu \mathrm{g} / \mathrm{ml}$. Effects of untreated as well as free AMPS spiked with equivalent amount of CNTs as control groups of treatment were also evaluated. Experimental data revealed that none of the above treatments were toxic to the macrophage cell lines THP-1 (Fig. 2b, f). Similar results were also observed in Raw 264.7 (data not shown).

\section{Expression of selected innate immune genes}

Objective, of the current work, is to understand potential of LL-37 and indolicidin in modulating expression of innate immune genes. Following the establishment of AMP toxicity to cell lines, we, therefore, evaluated the effects of AMP treatment on select innate immune gene expression to understand AMPs potential as an immune stimulant that facilitates antimicrobial activity. Expression kinetics of few select innate immune genes in THP-1 cells following peptide treatment at $20 \mu \mathrm{g} / \mathrm{ml}$ and CNT conjugated peptide at $0.02 \mu \mathrm{g} / \mathrm{ml}$ revealed that, optimal expression of genes occurred at $6 \mathrm{~h}$ (Fig. 1h, i). Expression values for a few innate immune genes at the transcriptional level in THP-1 cells following $6 \mathrm{~h}$ treatment with free LL-37 at concentrations of 1, 10 and $20 \mu \mathrm{g} / \mathrm{ml}$ were determined by qRT-PCR. Experimental data revealed that with increasing concentration of LL-37, the expression at a transcriptional level for the genes IFNB1, IFNA, IL6, IL10, IL12, TNFA and NFKB1 increased with respect to time matched untreated controls (Fig. 2c). When the expression of the above-mentioned genes were calculated in THP-1 cells at $6 \mathrm{~h}$ following treatment with $0.02 \mu \mathrm{g} /$ $\mathrm{ml}$ of conjugated LL-37, it was observed that the expression of these genes was similar (1-way ANOVA, $\mathrm{p} \geq 0.05$, $\mathrm{n}=3$ ) in comparison to free LL-37 which was treated with a higher dose of $20 \mu \mathrm{g} / \mathrm{ml}$ (Fig. 2c). Similarly, with increasing dose of free indolicidin, the above mentioned innate immune gene expressions increased with respect to time matched untreated control (Fig. 2g). Statistical analysis using 1-way ANOVA ( $\mathrm{p} \geq 0.05, \mathrm{n}=3$ ) confirms 


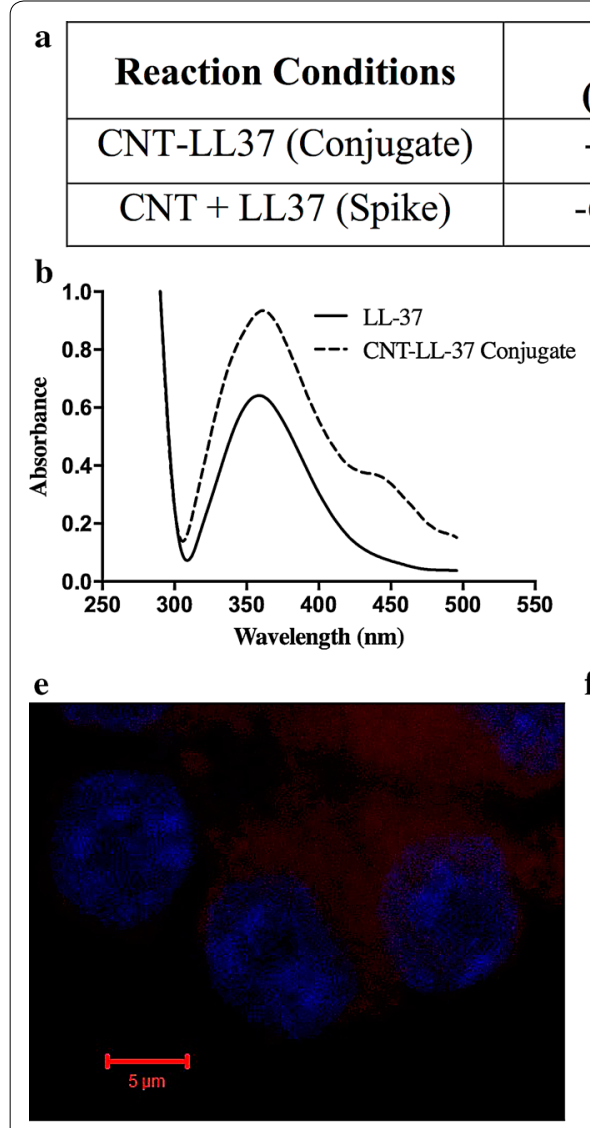

h

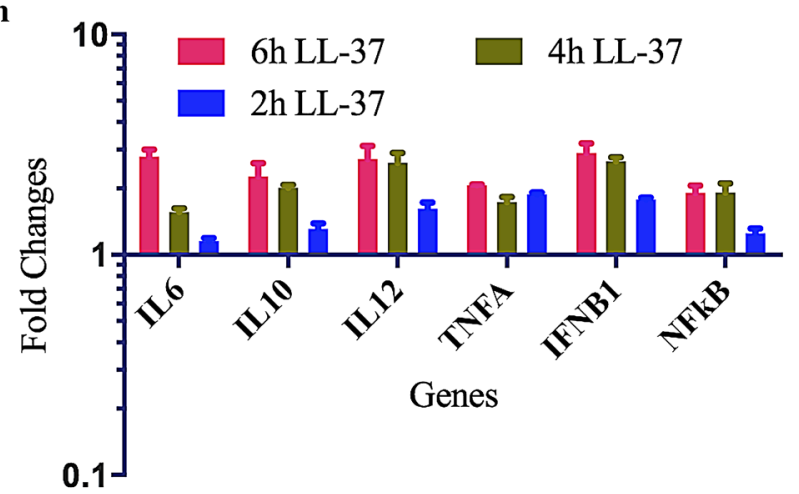

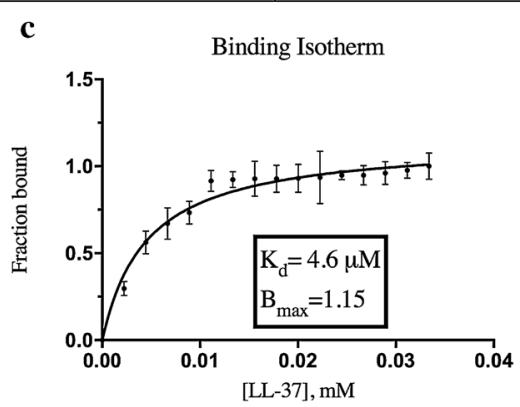

d

f
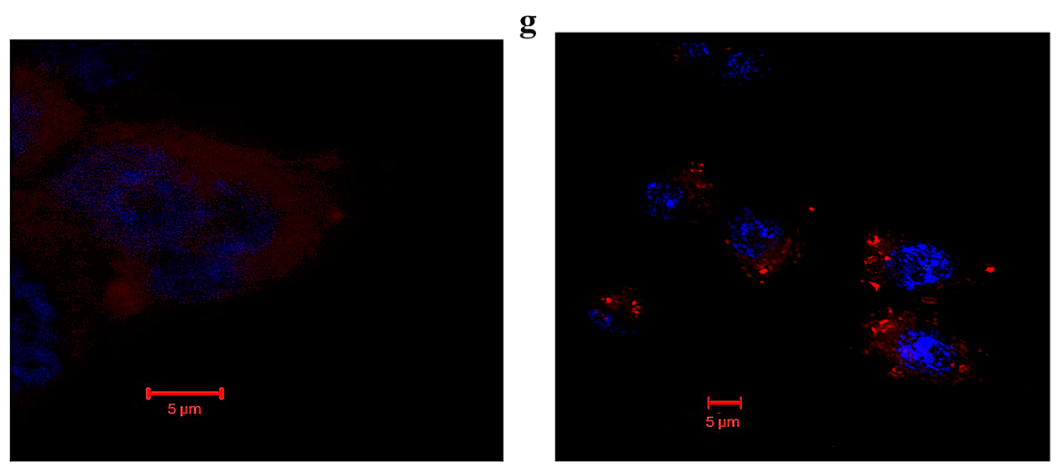

i

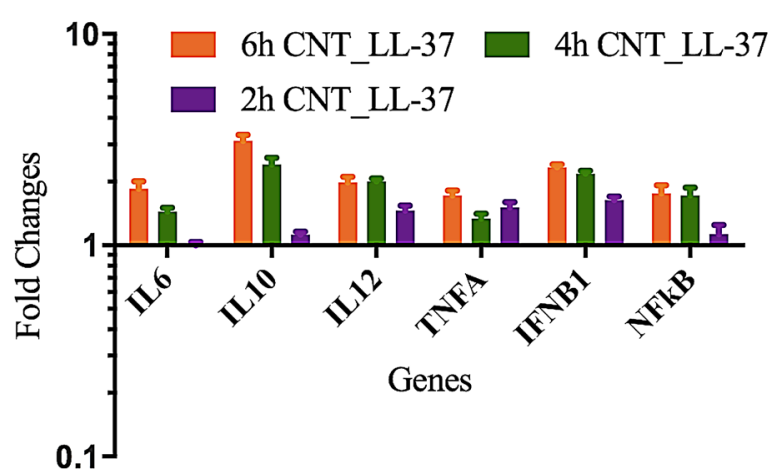

Fig. 1 Characterization of CNT-peptide conjugate and its uptake by the macrophage cellls. Characterization of conjugation of CNT and LL-37 using a isothermal calorimetry, b UV-visible spectroscopy, $\mathbf{c}$ binding isotherm plot, d FT-IR spectrum. Uptake studies of Cy3 labeled free (f) and CNT-conjugated peptide (g) by THP-1 cells using confocal microscopy following $2 \mathrm{~h}$ of treatment. Untreated unlabelled control image is shown in e. Kinetics of gene expression of a few innate immune genes in THP-1 cells following treatment with free LL-37 at $20 \mu \mathrm{g} / \mathrm{ml}(\mathbf{h})$ and CNT-LL37 at $0.02 \mu \mathrm{gg} / \mathrm{ml}(\mathbf{i})$. Error bars shown are representative of $\pm 1 \mathrm{SD}$

that the gene expression pattern was almost similar in $20 \mu \mathrm{g} / \mathrm{ml}$ indolicidin treated cells with respect to $0.02 \mu \mathrm{g} /$ $\mathrm{ml}$ indolicidin conjugated cells (Fig. $2 \mathrm{~g}$ ). It is clear, that, both of the conjugated peptides can induce controlled up-regulation of select innate immune genes at a lower dosage (1000 fold less) than that of the free peptides.

\section{Protection against ST challenge}

When innate immune genes are moderately (fold changes up to 5) up-regulated in macrophages, we defined the macrophages as primed [38]. Primed macrophages have the ability to combat bacterial pathogens more efficiently than naive macrophages. To prove this hypothesis, 

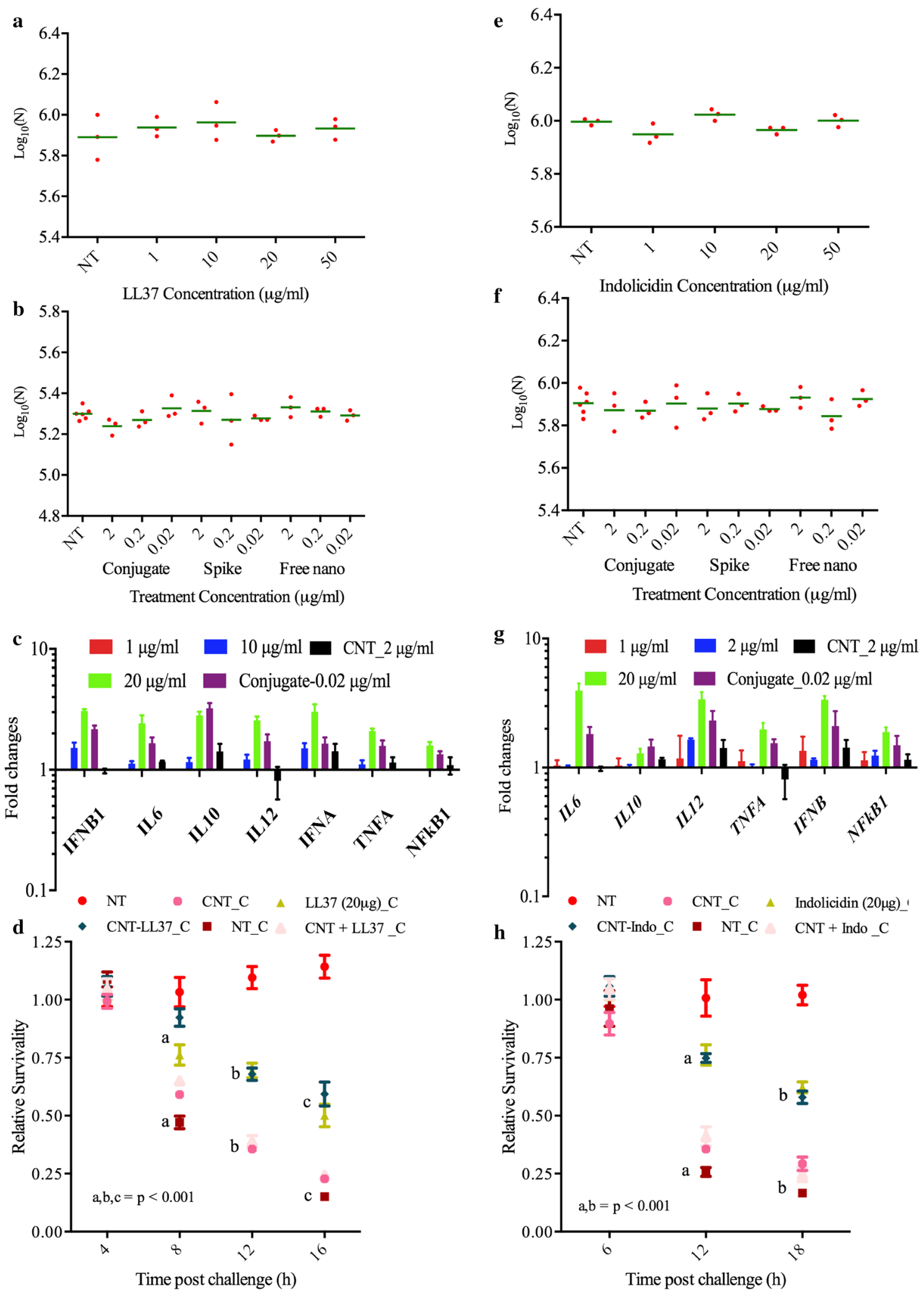
(See figure on previous page.)

Fig. 2 Viability of nano conjugated HDPs followed by gene expression modulation and protection of cells against Salmonella challenge. Viability of THP_1 cells following treatment with various concentrations of a LL-37, b CNT, CNT conjugated LL-37 and LL-37 spiked CNT, e indolicidin and f $C N T$, CNT conjugated indolicidin and indolicidin spiked CNT. Expression of select innate immune genes in Thp1 cells following treatment with $\mathbf{c} L L-37$ and CNT conjugated LL-37 and $\mathbf{g}$ indolicidin and CNT-conjugated indolicidin. Relative survivability of THP-1 cells being challenged by Salmonella in the absence or presence of $\mathbf{d}$ free LL-37 at $20 \mu \mathrm{g} / \mathrm{ml}$ or CNT conjugated LL-37 at $0.02 \mu \mathrm{g} / \mathrm{ml}$ and $\mathbf{h}$ free indolicidin at $20 \mu \mathrm{g} / \mathrm{ml}$ or CNT conjugated indolicidin at $0.02 \mu \mathrm{g} / \mathrm{ml}$. Significant changes with $p \leq 0.001$ at each time point is shown in letters

free LL-37 and indolicidin, as well as conjugated AMPs primed THP-1 cells, were exposed to ST at MOI of 10 . Results revealed that macrophage cells primed with free LL-37 at $20 \mu \mathrm{g} / \mathrm{ml}$ and CNT-LL-37 at $0.02 \mu \mathrm{g} / \mathrm{ml}$ were significantly (2-way ANOVA, $\mathrm{p} \leq 0.001, \mathrm{n}=12$ ) protected against ST challenge with respect to the unprimed cells (Fig. 2d). Primed cell survivability was found to be 80,65 and 55\%, whereas, unprimed cell survival was 48, 36 and $14 \%$ at 8,12 and 16 h post challenge. Similarly, THP-1 cells primed with free indolicidin at $20 \mu \mathrm{g} / \mathrm{ml}$ and CNT-indolicidin at $0.02 \mu \mathrm{g} / \mathrm{ml}$ were significantly (2-way ANOVA, $\mathrm{p} \leq 0.001, \mathrm{n}=12$ ) protected against ST infection. The survivability of primed cells was found to be 75 and $55 \%$, whereas, the survival of unprimed cells was 28 and $17 \%$ at $12 \mathrm{~h}$ and $18 \mathrm{~h}$ post challenge (Fig. $2 \mathrm{~h}$ ). The results from our pathogenic challenge study revealed that conjugating LL-37 and indolicidin with SM-CNT increased their immune modulatory efficacy by 1000 folds. However, the exact mechanism through which priming occurs is yet to be elucidated. Therefore, we conducted genome wide transcriptional gene expression microarray studies to understand the plethora of genes that could be responsible for priming.

\section{Genome wide gene expression to elucidate transcriptional pathway biology in vitro}

We performed experiments with a view to understanding genome wide transcriptomic profiling by studying gene expression changes in THP-1 cells following treatment with either unconjugated LL-37 or indolicidin at $20 \mu \mathrm{g} / \mathrm{ml}$ or CNT conjugates at $0.02 \mu \mathrm{g} / \mathrm{ml}$ of either conjugate. For control studies, cells were also treated with free CNT or free AMP or AMPs spiked with SM$\mathrm{CNT}$ at their respective conjugate concentrations. The genes were considered to be differentially expressed and statistically significant, if fold changes were $\geq 1.5$ with $\mathrm{p} \leq 0.05$. There were total of 3784, 1535, 2197, 1563 genes that were differentially expressed in THP-1 cells following $6 \mathrm{~h}$ treatment with CNT, CNT + LL-37, CNT-LL-37 and LL-37-20 respectively (Fig. 3a). Out of which $3171,489,488,835$ genes were unique in THP-1 cells at $6 \mathrm{~h}$ following treatment with CNT, CNT + LL-37, CNT-LL-37 and LL-37-20. Similarly, a total of 3784, 2446, 2221 and 2015 genes were differentially expressed in THP-1 cells at $6 \mathrm{~h}$ following treatment with CNT,
$\mathrm{CNT}+$ indolicidin, CNT-indolicidin and indolicidin-20 respectively (Fig. 3c). Out of these differentially expressed genes, 1172, 1172, 885 and 1109 were uniquely expressed at $6 \mathrm{~h}$ following treatment with CNT, CNT + indolicidin, CNT-indolicidin and indolicidin-20.

The genes were clustered using GeneAnalytics to find out the biological pathways that are populated most. The top 5 pathways related to innate immune signalling and cell cycle regulation are listed in Table 1 . Innate immune signalling was enriched with 90 genes in THP-1 cells treated with free indolicidin as well as CNT conjugated indolicidin. There are 46 genes enriched with infectious disease signalling in the THP-1 cells treated with free LL-37 as well as conjugated LL-37. LL-37 also activates TGF $\beta$ signaling in THP-1 cells, which indicates feedback suppression of inflammatory pathways. The expression levels of these enriched genes are comparable in free peptide as well as CNT conjugated peptide treatments, but at 1000 fold less concentration (Additional file 2: Table S2, Additional file 3: Table S3). Important genes with their expression level and function are listed in Table 2 (for LL-37) and in Table 3 (for indolicidin). The gene expression profile revealed that conjugated AMPs show similar effects as free AMPs, but at a 1000-fold lower concentration (Tables 2, 3). It was also observed that when indolicidin spiked with $\mathrm{CNT}$, the gene expression profile was better than free peptide at $0.02 \mu \mathrm{g} / \mathrm{ml}$ but we did not find this phenomenon in case of LL-37. This may be due to indolicidin stacking over the CNT surface via $\pi$ electron cloud overlap of both the substances; increasing the effectiveness of indolicidin delivery into the cell through the added hydrophobicity from CNT. However, more study needs to be done to confirm this phenomenon.

We have tried to populate the pathways with important innate immune genes which were differentially expressed following treatment with both of the conjugates. From the list of differential gene expression, we searched for receptors, adaptors, kinases and transcription factors which are related to immune signaling and match them with the KEGG pathways. The genes of NFkB1 pathway and its downstream genes are up-regulated in THP-1 cells following LL-37 and CNT-LL-37 treatment. It was also observed that interleukin 1 receptor and its subsequent adaptors and kinases such as Myd88, Traf6 and Map3k7 was up-regulated in THP-1 cells following LL-37 and its 

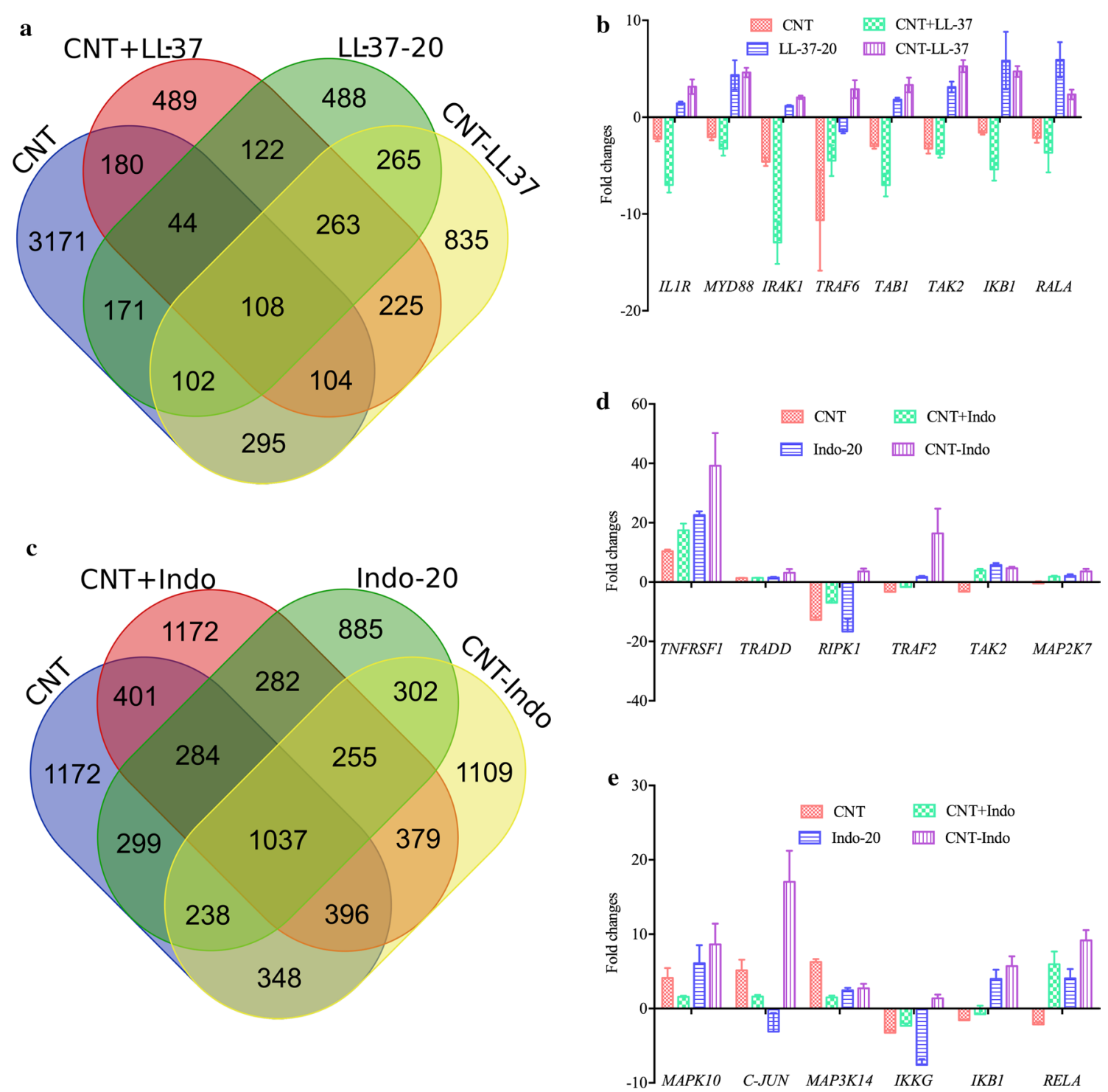

Fig. 3 Venn diagram of genome wide gene expression at various treatments conditions and expression profile of select genes. Venn diagram is showing number of differentially expressed (up- or down-regulated) genes following $6 \mathrm{~h}$ treatment of Thp 1 with a LL-37, CNT-LL-37, CNT and CNT + LL37 and c indolicidin, CNT-indolicidin, CNT and CNT + indolicidin. Validation microarray data by qRT of a few important and select genes of b IL1 signaling pathway in THP-1 cells following treatment with free and conjugated or spiked LL-37 and, d, e TNF signaling pathway in THP-1 cells following treatment with free, nano-conjugated or spiked indolicidin

Table 1 Top 5 enriched pathways in THP-1 following $6 \mathrm{~h}$ treatment with LL-37 and indolicidin

\begin{tabular}{lllll}
\hline LL-37 & & & Indolicidin \\
Pathways & Enriched gene number & & Pathways & Enriched gene number \\
\hline AKT signaling & 63 & Innate immune system & 90 \\
Infectious diseases & 46 & MAPK signaling & 54 \\
IGF1R signaling & 20 & AKT signaling & 55 \\
TGFB signaling & 20 & TNF signaling & 21 \\
Cell cycle & 22 & Chemokine signaling & 26 \\
\hline
\end{tabular}


Table 2 Important genes differentially expressed in THP-1 following $6 \mathrm{~h}$ treatments with LL-37

\begin{tabular}{|c|c|c|c|c|c|c|}
\hline \multirow[t]{2}{*}{ Gene symbol } & \multicolumn{4}{|c|}{ Fold changes WRT NT } & \multirow[t]{2}{*}{ Entrez ID } & \multirow[t]{2}{*}{ Function } \\
\hline & CNT & LL37-20 & CNT-LL37 & CNT + LL37 & & \\
\hline TSG101 & 2.1 & 1.0 & 6.8 & 1.0 & 7251 & Acts as a negative growth regulator \\
\hline GRB2 & 1.5 & 1.0 & 5.2 & 1.0 & 2885 & Links cell surface GFRs and the Ras signaling pathway \\
\hline IL9R & 1.0 & 2.6 & 2.6 & 2.5 & 3581 & Interleukin-3, 5 and GM-CSF signaling \\
\hline MAP4K3 & 1.0 & 1.7 & 6.2 & 1.0 & 8491 & MAPK signaling pathway and TNF signaling \\
\hline CFLAR & 1.0 & 1.0 & 6.3 & 1.0 & 8837 & Acts as an inhibitor of TNFRSF6 mediated apoptosis \\
\hline ENPP1 & 3.0 & 1.0 & 7.0 & 1.0 & 5167 & Appears to modulate insulin sensitivity and function \\
\hline RALBP1 & 1.0 & 3.1 & 4.5 & -2.6 & 10928 & Can catalyze transport of glutathione and xenobiotics \\
\hline SUCLA2 & -1.8 & 4.0 & 5.6 & 4.8 & 8803 & Catalyzes succinyl-CoA production \\
\hline ALOX5 & 1.0 & 1.0 & 6.0 & 1.0 & 240 & Catalyzes leukotriene biosynthesis and inflammation \\
\hline MAOB & 1.0 & 4.6 & 4.3 & 1.0 & 4129 & Oxidative deamination of biogenic and xenobiotic amines \\
\hline $\mathrm{CCL} 20$ & 5.5 & 9.2 & 10.1 & 1.0 & 6364 & $\begin{array}{l}\text { Chemotactic to lymphocytes and neutrophils. Possesses antibacterial } \\
\text { activity E. coli and S. aureus }\end{array}$ \\
\hline IL33 & 1.0 & 1.0 & 3.5 & 1.0 & 90865 & Activates NF-kappa-B and MAPK signaling pathways \\
\hline IL36G & 1.0 & 2.9 & 3.8 & 2.7 & 56300 & Activates NF-kappa-B and MAPK signaling pathways \\
\hline SLC2A14 & 1.0 & 1.0 & 4.1 & 3.3 & 144195 & Facilitative glucose transporter \\
\hline DEFB105B & 1.0 & 1.0 & 2.8 & 1.0 & 504180 & Has antibacterial activity \\
\hline DEFA5 & 1.0 & 1.0 & 5.0 & 1.0 & 1670 & Antimicrobial activity against broad spectrum bacteria \\
\hline EFR3A & -25.4 & 1.0 & 7.3 & 1.0 & 23167 & Signaling through PIP3K and G protein couples receptors \\
\hline PLA1A & 1.0 & 6.2 & 5.2 & 1.0 & 51365 & Stimulate histamine production \\
\hline INO80B & 1.0 & 1.0 & 2.8 & 1.0 & 83444 & Cell cycle arrests at the $\mathrm{G} 1$ phase of the cell cycle \\
\hline TLE1 & 1.0 & 3.8 & 5.8 & 1.0 & 7088 & Inhibits NF-kappa-B-regulated gene expression \\
\hline SKP2 & 1.0 & 2.3 & 7.1 & 1.0 & 6502 & involved in regulation of $\mathrm{G} 1 / \mathrm{S}$ transition \\
\hline NLRC4 & 1.0 & 1.0 & 2.9 & 1.0 & 58484 & $\begin{array}{l}\text { Senses specific proteins from pathogenic bacteria and fungi and responds } \\
\text { by assembling an inflammasome complex }\end{array}$ \\
\hline BTG3 & 1.0 & 5.7 & 6.1 & 1.0 & 10950 & Blocks cell cycle at G0/G1 to S phase \\
\hline SLC22A15 & 5.6 & 1.0 & 9.5 & 9.0 & 55356 & Probably transports organic cations \\
\hline IL11RA & 1.0 & 3.6 & 3.2 & 1.0 & 3590 & Involved in macrophage proliferation and differentiation \\
\hline OGFOD2 & 1.0 & 4.9 & 6.9 & 5.4 & 79676 & Iron ion binding and oxidoreductase activity \\
\hline IL17RE & 1.0 & 1.0 & 3.9 & 3.8 & 132014 & crucial regulator in innate immunity to bacterial pathogens \\
\hline CCNE2 & 1.0 & 4.7 & 4.5 & 3.2 & 9134 & Blocks cell cycle at the G1-S phase \\
\hline IRF1 & 1.0 & 1.0 & 4.7 & 1.0 & 3659 & Regulation of IFNs against viral and bacterial infections \\
\hline
\end{tabular}

CNT conjugate treatment. From this it may be inferred that LL-37 signals through the interleukin 1 receptor (IL1R) followed by nuclear factor kappa B1 (NFkB1) translocation to nucleus with subsequent transcription of pro-inflammatory cytokines, chemokines and defensins. We also observed the expression of genes related to cell proliferation and differentiation along with up-regulation of calcium transporter (CACNA1B), protein phosphatase 3 catalytic subunit alpha (PPP3CA) and NFAT2. It may be inferred that calcium release to cytoplasm through CACNA1B activated PPP3CA which in turn dephosphorylate the transcription factor NFAT2 which is subsequently translocated to the nucleus to transcribe genes related to cell proliferation and differentiation. The above pathway is represented in Fig. 4a. The genes involved in this pathway were also validated through qRT-PCR and represented with their fold changes with respect to untreated time matched controls in Fig. 3b.

It was also observed that many genes related to proinflammation, cell proliferation and cell differentiation were significantly up-regulated in THP-1 cells following treatment with indolicidin and $\mathrm{CNT}$ conjugated indolicidin. Tumor necrosis factor receptor 1a (TNFSF1A), MAP3K11, MAP3K14, NFKB and c-JUN are up-regulated in THP-1 cells following treatment with indolicidin. From this gene expression data, it may be inferred that TNFRSF1A signals through MAP3K11 and MAP3K14 followed by activation of transcription factors NFKB1 and c-JUN. Eventually the genes related to cell proliferation, differentiation and pro-inflammation get activated in 
Table 3 Important genes differentially expressed in THP-1 following 6 h treatments with indolicidin

\begin{tabular}{|c|c|c|c|c|c|c|}
\hline \multirow[t]{2}{*}{ Gene symbol } & \multicolumn{4}{|c|}{ Fold changes WRT NT } & \multirow[t]{2}{*}{ Entrez Gene ID } & \multirow[t]{2}{*}{ Gene functions } \\
\hline & CNT & CNT + Indo & CNT-Indo & Indo-20 & & \\
\hline TNFRSF1A & 6.5 & 42.3 & 29.0 & 33.2 & 7132 & Activate NFkB, mediated regulator of inflammation \\
\hline RBCK1 & 3.4 & 10.9 & 6.9 & 1.0 & 10616 & Activation of canonical NFkB and the JNK signaling \\
\hline \multirow[t]{2}{*}{ SLC11A1 \& SLC5A5 } & 4.4 & 6.1 & 6.9 & 4.3 & 6556 & \multirow{2}{*}{$\begin{array}{l}\text { Transport of glucose and other sugars, bile salts and organic acids, } \\
\text { metal ions and amine compounds }\end{array}$} \\
\hline & 2.2 & 5.0 & 8.7 & 1.8 & 6528 & \\
\hline ENPP7 & 5.1 & 12.1 & 16.3 & 8.5 & 339221 & Converts sphingomyelin to ceramide \\
\hline SOSTDC1 & 2.8 & 2.5 & 5.0 & 2.5 & 25928 & Enhances Wnt and inhibits TGF-beta signaling \\
\hline XPR1 & 1.0 & 1.6 & 47.6 & -1.9 & 9213 & G-protein coupled receptor activity \\
\hline S100A5 & 69.2 & 67.4 & 150.4 & 113.5 & 6276 & Helps in cell cycle progression and differentiation \\
\hline NAPEPLD & 8.0 & 25.7 & 22.6 & 17.7 & 222236 & $\begin{array}{l}\text { Responsible for the generation of anandamide, the ligand of can- } \\
\text { nabinoid and vanilloid receptors }\end{array}$ \\
\hline RGS11 & 2.1 & 3.0 & 5.9 & 1.9 & 8786 & Inhibits signal transduction by G Protein \\
\hline RGS6 & 1.0 & -1.6 & 5.9 & 1.5 & 9628 & Inhibits signal transduction by $\mathrm{G}$ protein \\
\hline RUSC1 & 1.1 & -1.0 & 5.7 & 1.6 & 23623 & Activation of the NFkB pathway \\
\hline IBA57 & 2.5 & 4.0 & 4.9 & 1.0 & 200205 & Activates iron-sulfur cluster assembly pathway \\
\hline MYO5B & 1.0 & -1.3 & 13.7 & -1.0 & 4645 & Vesicular trafficking with the CART complex \\
\hline $\mathrm{AOX} 1$ & 2.8 & 2.7 & 4.7 & 2.6 & 316 & Regulation of reactive oxygen species homeostasis \\
\hline RIPK4 & 3.7 & 7.3 & 6.9 & 1.4 & 54101 & Plays a role in NF-kappa-B activation \\
\hline FILIP1L & 2.0 & 10.6 & 14.0 & 2.2 & 11259 & Leads to inhibition of cell proliferation and migration \\
\hline NCOA4 & 2.4 & 5.9 & 10.6 & 5.8 & 8031 & Co-activator of the PPARG \\
\hline CREB3L3 & 1.7 & 7.0 & 4.5 & 4.9 & 84699 & Linked to acute inflammatory response \\
\hline RASSF2 & 6.5 & 6.7 & 12.2 & 7.3 & 9770 & May promote apoptosis and cell cycle arrest \\
\hline DAP & 2.8 & 1.7 & 7.0 & 2.7 & 1611 & Negative regulator of autophagy \\
\hline RELA & -1.2 & 1.7 & 8.4 & -1.2 & 5970 & NFkB pleiotropic transcription factor \\
\hline CCL20 & 5.5 & 1.5 & 10.9 & 11.0 & 6364 & Antibacterial activity against E. coli and S. aureus \\
\hline LYRM4 & 3.3 & 3.4 & 6.2 & 2.2 & 57128 & Nuclear and mitochondrial FE-S protein biosynthesis \\
\hline $\mathrm{ZDHHC22}$ & 17.0 & 41.5 & 44.6 & 44.4 & 283576 & Feedback regulator of calcium mediated signaling \\
\hline CYP3A5 & 3.7 & 3.6 & 6.9 & 3.7 & 1577 & Oxidizes steroids, fatty acids, and xenobiotics \\
\hline
\end{tabular}

THP-1 cells. This pathway was represented schematically in Fig. $4 \mathrm{~b}$ and the genes shown were validated through qRT-PCR and plotted with their fold changes with respect to untreated time matched controls in Fig. 3d, e.

\section{Discussion}

Cationic AMPs are non-toxic to cells up to a concentration of $50 \mu \mathrm{g} / \mathrm{ml}$ [40]. Our findings corroborate with this pre-established level of AMP toxicity. Our results revealed that following LL-37 and indolicidin treatment up to $50 \mu \mathrm{g} / \mathrm{ml}$, human and mice macrophage cells show no toxic effects (Fig. 2a, e). The immune modulatory properties of AMPs include modulating pro- and antiinflammatory responses through [41] various signaling pathways [40] directly [42] or indirectly [43] recruiting effector cells including phagocytes to the site of infection, enhancing intracellular [44] and extracellular [45] bactericidal activity. AMPs also mediate macrophage differentiation [46] which is required for effective clearance of pathogens from the host. AMPs also induce apoptosis
[47] and pyroptosis [48] in the infected cells as a means of clearing pathogens. Despite their effectiveness in pathogen clearance, host defense peptides (HDPs) were not popular for clinical usage because of their high synthesis cost [49]. There is a need to improve the efficacy of AMPs and we tried to accomplish this by conjugating LL-37 and indolicidin to carboxylated CNT. We compared immune modulatory properties of these two peptides in treated macrophages, both in free and CNT conjugated state.

\section{Role of LL-37, indolicidin and their CNT conjugates} in modulating pro- and anti-inflammation in THP-1 human macrophage cells

LL-37 activates the canonical NFkB pathway responsible for modulating the expression of various genes involved in the innate immune system [19]. Our results revealed that the expression of pro-inflammatory genes that play a critical role in regulating the NFKB pathway [RELA, TNFRSF1A, TRAF6, ATM and BTRC (Additional file 2: Table S2)] are up-regulated upon CNT-LL-37 treatment; 

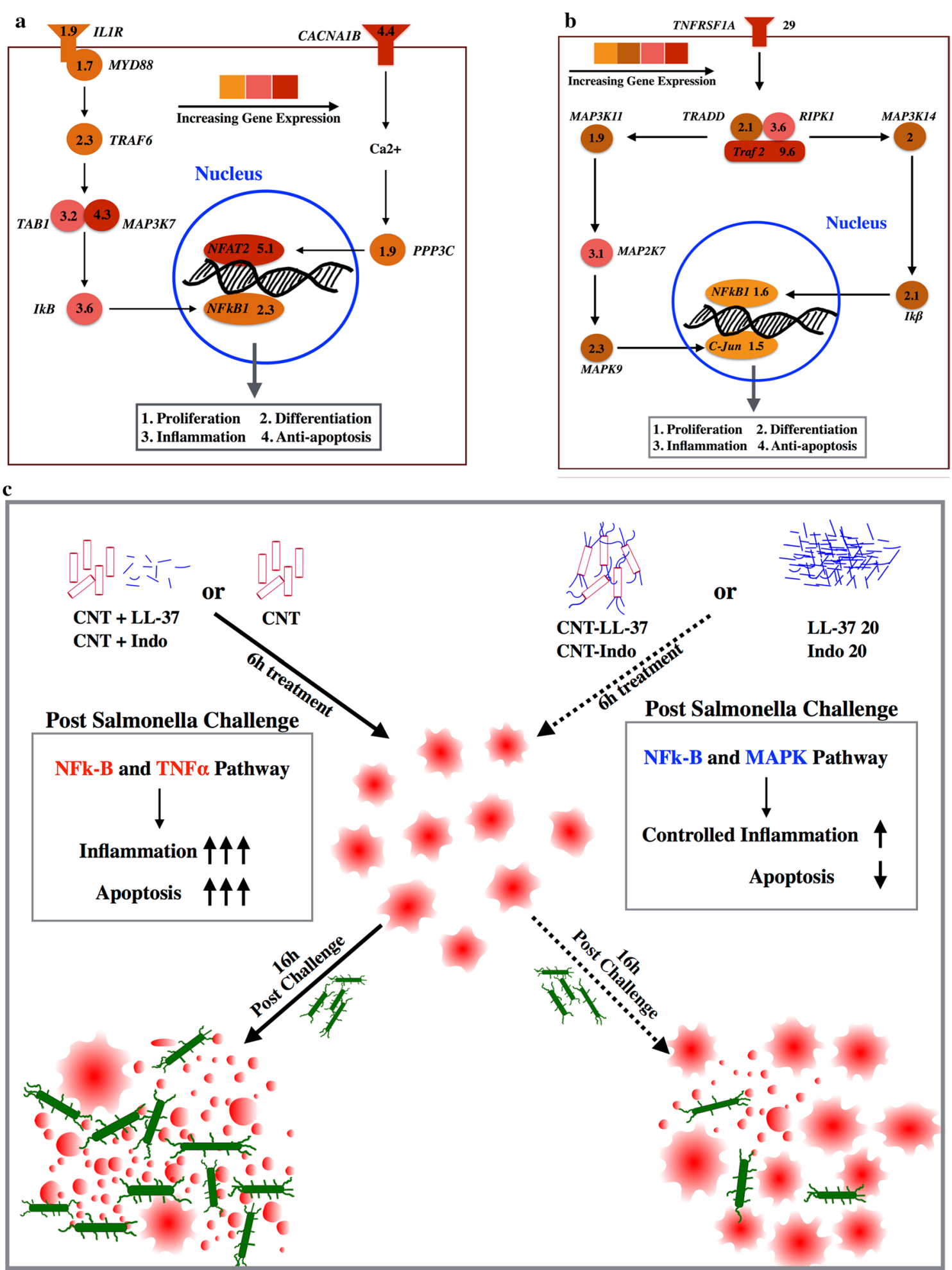

Fig. 4 Pathways that were indicated by genome wide microarray data and validated by qRT-PCR results following treatment with nano-conjugated LL-37 and indolicidin. Activation of a IL 1 pathway in THP-1 cells following treatment with conjugated LL-37 at $0.02 \mu \mathrm{g} / \mathrm{ml}, \mathbf{b}$ TNF pathway via TNFRSF1A in THP-1 cells following treatment with conjugated indolicidin at $0.02 \mu \mathrm{g} / \mathrm{ml}$. c Graphical summary of the consolidated schema of the current study depicting how LL-37 and indolicidin primed Thp1 cells to protect against Salmonella infection 
notably, LL-37 conjugate treated cells also show almost the same expression pattern, but at 1000 fold less concentration than free LL-37. The expression profile of TNFRSF1A, LELA, RIPK4, RUSC1 and RBCK1 genes in CNT-indolicidin as well as free indolicidin treated cells confirms pro-inflammation mediated by the NFKB pathway. LL-37 induced signaling through the $\mathrm{P}^{38}$ MAPK pathway, followed by activation of genes responsible for macrophage differentiation, pro-inflammation and proliferation [50]. Activation of 36 genes (Additional file 2: Table S2) related to the P38 MAPK pathway following LL-37 treatment, and up-regulation of several genes (Additional file 3: Table S3) following indolicidin treatment confirmed that the conjugates stimulate signaling similar to that of the free peptide, but at a 1000-fold lower dose. Through the interaction of phosphoinositide 3-kinase (PI3 K), NFKB and MAPK pathways, LL-37 induced IL-1B, followed by pro-inflammation in monocytes and macrophages [51]. Expression of IL1B (Additional file 2: Table S2, Additional file 3: Table S3) in THP-1 cells following LL-37 and indolicidin conjugate treatment indicates that conjugated AMPs can induce pro-inflammation in macrophages at the same levels stimulated by free peptides, but at a 1000-fold lower concentration. AMPs can also induce the production of IL17 and reactive oxygen species (ROS), enhancing the phagocytic activity of macrophages and capacity for clearing pathogens within the phagosome [52]. Expression of IL17RE (Table 2) in THP-1 cells following treatment with LL-37 as well CNT conjugated LL-37 indicates a similar effect of the conjugate on macrophages. This is a controlled inflammation, indicated by the moderate expression of anti-inflammatory cytokine IL10 along with pro-inflammatory cytokines IL6, IL12, IL1a, IFNa and IFNb (Fig. 2c, g) in the conjugate treatments as well as free LL-37 and indolicidin treatments at $20 \mu \mathrm{g} / \mathrm{ml}$. This data indicated that LL-37 and indolicidin conjugates are similarly effective in modulating pro-inflammatory pathways as their free peptide forms, but at 1000 fold less concentration.

\section{Role of LL-37, indolicidin and their CNT conjugates in modulating chemokine expression in the THP-1 human macrophage cell line}

AMPs are chemo attractants for monocytes, neutrophils, macrophages and T-cells. These molecules can induce various chemokines and chemokine receptors in macrophages to attract these immune cells to the site of infection $[43,53]$. Expression of CCL20, CCL4 and CCL19 (Table 2) in CNT-LL-37 and CCL20, CCL19, CCL7, CCL4 (Table 3) in indolicidin conjugate treated THP-1 cells indicates that both conjugates are able to stimulate similar signaling pathways involved in macrophage chemotaxis. However, this conclusion needs to be verified in vivo.

\section{Additional functions of free and conjugated AMPs in THP-1 cells}

AMPs induce autophagy in infected macrophages to facilitate the clearance of intercellular debris, which is controlled through ATG5 gene [54]. Expression of ATG5 in LL-37 and its CNT conjugate treated cells might result in similar autophagic activity. However, CNT itself is a very efficient autophagic inducer, as CNT treatment shows 16 fold up-regulation of ATG5 in THP-1 cells. Apart from enhancing the efficacy of AMPs, CNT itself has this added effect. LL-37 and beta-defensin, induce epidermal growth factor receptor (EGFR) signaling, followed by activation of the PI3 K-AKT and MAPK pathways responsible for cell proliferation during wound healing [55]. THP-1 cells treated with LL-37 and its conjugate also show activation of the PI3 K-AKT and MAPK signaling pathways (Table 1), as well as up-regulation of PDGFRA gene (Additional file 2: Table S2).

It is reported that LL-37 delays apoptosis in monocytes and neutrophils by activating $\mathrm{G}$ protein coupled receptor (GPCR) mediated signaling [47]. THP-1 cells treated with LL-37 or its conjugate also appear to exhibit active GPCR signaling as we have recorded the expression of GPR180, GPRC5C, GPR174 and GPR3 (Additional file 2: Table S2); similarly, THP-1 cells treated with indolicidin or its conjugate resulted in GPCR signaling as shown by the expression of GPR135, GPR176, GPR112, GPR110, GPR173 and GPR3 (Additional file 3: Table S3). Compared to LL-37, indolicidin imparts more pro-inflammatory effects in THP-1 cells; however, the regulation of inflammation through TGF $\beta$ and IL10 pathway was stronger in LL-37 treated cells, indicated by the genes listed in Table 4. The overall mechanism through which LL-37, indolicidin and their CNT conjugates protect macrophages from salmonella induced cytotoxicity could be graphically summarized, as depicted in Fig. 4c.

Data from Salmonella challenge studies revealed that, LL-37 or indolicidin primed THP-1 cells can efficiently protect themselves against ST induced cytotoxicity for $16 \mathrm{~h}$ post challenge. The genome wide gene expression study shows that pro-inflammatory and anti-apoptotic signaling in THP-1 cells treated with indolicidin may be mediated through TNFRSF1A, followed by activation of $N F \kappa B$ and $c-J U N$. However, pro-inflammation, cell proliferation and cell differentiation in THP-1 following LL-37 treatment may mediated through $I L 1 R$, followed by activation of NFKB and NFAT2. Though immune modulation by LL-37 and indolicidin was partly known before, our data established the complete gene expression and signaling mechanism. The conjugation strategy enhanced 
Table 4 LL-37 and indolicidin modulates immune genes and pro-apoptotic genes differently

\begin{tabular}{|c|c|c|c|c|c|c|c|c|}
\hline Gene symbol & CNT & CNT + Indo & CNT-Indo & Indo-20 & CNT + LL37 & CNT-LL37 & LL37-20 & Gene description \\
\hline ANAPC11 & -2.4 & 1.2 & 1.7 & -1.4 & 1 & 1 & 1 & Anaphase promoting complex subunit 11 \\
\hline CCL20 & 5.5 & 1.5 & 10.9 & 11 & 1 & 10.1 & 9.2 & Chemokine (C-C motif) ligand 20 \\
\hline DEFA3 & 1.1 & 1 & 1.6 & 1.1 & 1 & 1 & 1 & Defensin, alpha 3 \\
\hline IL31RA & 1.4 & -6.7 & 1.6 & -1 & 1 & 4.4 & 1 & Interleukin 31 receptor A \\
\hline NFATC2 & 3.1 & 2.1 & 4.3 & 1.9 & 1.7 & 4.9 & 12.4 & $\begin{array}{l}\text { Nuclear factor of activated T-cells, cytoplasmic, } \\
\text { calcineurin-dependent } 2\end{array}$ \\
\hline NFATC2IP & 1.3 & -1.8 & 2 & 1.1 & 1 & 1 & 1 & $\begin{array}{l}\text { Nuclear factor of activated T-cells, cytoplasmic, } \\
\text { calcineurin-dependent } 2 \text { interacting protein }\end{array}$ \\
\hline PKMYT1 & -1 & -1.4 & 1.6 & -1.3 & 1 & 1 & 1 & $\begin{array}{l}\text { Protein kinase, membrane associated tyrosine/ } \\
\text { threonine } 1 \text { (PKMYT1) }\end{array}$ \\
\hline RB1 & -3.3 & -4.1 & 1.6 & 1.6 & 1 & 1 & 1 & Retinoblastoma 1 \\
\hline SMAD3 & -1.3 & -2.3 & 2.5 & 1.2 & 1 & 2.5 & 1 & Mad protein homolog \\
\hline TGFBR1 & 1 & -1 & 1.5 & -1.1 & 1 & 2.5 & 1.7 & Transforming growth factor, beta receptor 1 \\
\hline CHEK1 & -3 & -1.1 & -6.5 & 1.6 & 1 & -3.9 & 1 & CHK1 checkpoint kinase \\
\hline CDKN2A & 1.5 & -1.2 & -4.2 & -2 & 1 & 4.6 & 4.3 & Cyclin-dependent kinase inhibitor $2 \mathrm{~A}$ \\
\hline TNFSF4 & 1.1 & 1 & -3.3 & 5.5 & 1 & -3.2 & -2.9 & $\begin{array}{l}\text { Tumor necrosis factor (ligand) superfamily, member } \\
4\end{array}$ \\
\hline CDC25C & -1 & -1 & -2.9 & 1 & -3.6 & 1 & 1 & Cell division cycle 25 homolog C \\
\hline CDC14B & -1 & -1.3 & -2.4 & -1.7 & -3.8 & -7.4 & 1 & CDC14 cell division cycle 14 homolog B \\
\hline GADD45B & 1.8 & -1.8 & -2.1 & -2 & 1 & 2.2 & 1.6 & Growth arrest and DNA-damage-inducible, beta \\
\hline TLR1 & -4.4 & -1.2 & -1.4 & -1.8 & 1 & 1 & 1 & Toll-like receptor 1 \\
\hline TLR3 & 1 & 1 & 2.3 & 1 & 1 & 2.8 & 1 & Toll-like receptor 3 \\
\hline TNFAIP3 & -2.5 & -7 & -9 & 1.6 & -4.4 & 1 & 1 & Tumor necrosis factor, alpha-induced protein 3 \\
\hline CCL14 & 4.3 & -1.3 & 3.9 & -1.2 & 1 & 1 & 1 & Chemokine ( $\mathrm{C}-\mathrm{C}$ motif) ligand 14 \\
\hline BCL2L2 & 1.4 & 2.7 & 2.5 & 1.1 & 1.1 & 3.2 & 1.3 & BCL2-like 2 \\
\hline Apaf1 & 4.3 & 1.1 & 1.1 & 1.0 & 1.2 & 1.1 & 1.1 & Apoptotic peptidase activating factor 1 \\
\hline
\end{tabular}

the immune modulating efficacy of these two peptides by 1000 fold, which will reduce the cost of these peptides for antimicrobial treatment, thereby increasing treatment access to a wider population of developing countries. Although LL-37 and indolicidin conjugation with CNT shows promise with regards to resisting ST infection in vitro, further trials need to be conducted in vivo for better understanding of its working mechanism.

\section{Conclusions}

Present study established an important fact for the usage of nanomaterials in biomedicine is that efficacy of a drug or a bio-agent can be enhanced by conjugating it with a suitable nanomaterial. Our results confirmed that at 1000-fold less concentration of either of the peptide, LL-37 or indolicidin, can be equally effective at $0.02 \mu \mathrm{g} /$ $\mathrm{ml}$ while the same is observed at $20 \mu \mathrm{g} / \mathrm{ml}$ with free peptides. The current report also established the efficacy of the conjugated peptide in protecting macrophage cells against salmonella challenge as well as mechanism by which the peptides are protecting is also reported.

\section{Additional files}

Additional file 1: Table S1. List of primers used to validate microarray through q-RTPCR.

Additional file 2: Table S2. Gene expression in terms of fold changes following treatment with free LL37, conjugates and other relevant controls.

Additional file 3: Table S3. Expression of genes in terms of fold changes following treatment free and conjugated Indolicidin and other conditions.

\section{Abbreviations}

AMPs: antimicrobial peptides; CNT: carbon nanotubes; SM-CNT: short multiwalled carbon nano-tubes; ST: Salmonella typhimurium serovar enterica; PMA: phorbol-12-myristate-13-acetate; qRT-PCR: quantitative real time polymerase chain reaction; MOl: multiplicity of infection; cDNA: complementary DNA; Webgestalt: WEB-based GEneSeT AnaLysis Toolkit.

\section{Authors' contributions}

$\mathrm{BP}$ executed most of the experiments and analyzed data. DG performed some experiments. BP and DG also assisted in writing the draft manuscript. AS and KM assisted in performing a few experiments. PR and DD helped in analyzing transcriptomic data. LL-37 was a gift from Professor REW Hancock of Hancock Lan, UBC, BC, Canada. PA conceptualized, supervised and finalized the work. All authors read and approved the final manuscript. 


\section{Acknowledgements}

Authors acknowledge the facility and infrastructure provided by NISER to execute the work.

\section{Competing interests}

The authors declare that they have no competing interests.

\section{Availability of data and materials}

All data generated or analysed during this study are included in this published article (and its Additional files 1, 2 and 3). However, if there is further query that can be addressed to the corresponding author.

\section{Funding}

Funding to support part of the work was approved by the Department of Science and Technology, Ministry of Science and Technology, Govt. of India with Grant \# SR/NM/NS-58/2010 to Palok Aich, PhD.

\section{Publisher's Note}

Springer Nature remains neutral with regard to jurisdictional claims in published maps and institutional affiliations.

Received: 10 March 2017 Accepted: 2 June 2017

Published online: 12 June 2017

\section{References}

1. Sur A, Pradhan B, Banerjee A, Aich P. Immune activation efficacy of indolicidin is enhanced upon conjugation with carbon nanotubes and gold nanoparticles. PLoS ONE. 2015;10:e0123905.

2. Tzeng Y-L, Ambrose KD, Zughaier S, Zhou X, Miller YK, Shafer WM, Stephens DS. Cationic antimicrobial peptide resistance in Neisseria meningitidis. J Bacteriol. 2005;187:5387-96.

3. Dürr UHN, Sudheendra US, Ramamoorthy A. LL-37, the only human member of the cathelicidin family of antimicrobial peptides. Biochim et Biophys Acta Biomembr. 2006;1758:1408-25.

4. Agerberth B, Gunne H, Odeberg J, Kogner P, Boman HG, Gudmundsson GH. FALL-39, a putative human peptide antibiotic, is cysteine free and expressed in bone marrow and testis. Proc Natl Acad Sci. 1995:92:195-9.

5. Johansson J, Gudmundsson GH, Rottenberg ME, Berndt KD, Agerberth B. Conformation-dependent antibacterial activity of the naturally occurring human peptide LL-37. J Biol Chem. 1998;273:3718-24.

6. Turner J, Cho Y, Dinh N-N, Waring AJ, Lehrer RI. Activities of LL-37, a cathelin-associated antimicrobial peptide of human neutrophils. Antimicrob Agents Chemother. 1998:42:2206-14.

7. Larrick JW, Hirata M, Zhong J, Wright SC. Anti-microbial activity of human CAP18 peptides. Immunotechnology. 1995;1:65-72.

8. Sorensen O, Arnljots K, Cowland JB, Bainton DF, Borregaard N. The human antibacterial cathelicidin, hCAP-18, is synthesized in myelocytes and metamyelocytes and localized to specific granules in neutrophils. Blood. 1997;90:2796-803.

9. Nilsson MF, Sandstedt B, Sørensen O, Weber G, Borregaard N, StåhleBäckdahl M. The human cationic antimicrobial protein (hCAP18), a peptide antibiotic, is widely expressed in human squamous epithelia and colocalizes with interleukin-6. Infect Immun. 1999;67:2561-6.

10. Larrick JW, Hirata M, Balint RF, Lee J, Zhong J, Wright SC. Human CAP18: a novel antimicrobial lipopolysaccharide-binding protein. Infect Immun. 1995:63:1291-7.

11. Cowland JB, Johnsen AH, Borregaard N. hCAP-18, a cathelin/pro-bactenecin-like protein of human neutrophil specific granules. FEBS Lett. 1995;368:173-6.

12. Bandurska K, Berdowska A, Barczynska Felusiak R, Krupa P. Unique features of human cathelicidin LL-37. BioFactors. 2015:41:289-300.

13. Kuroda K, Okumura K, Isogai H, Isogai E. The human cathelicidin antimicrobial peptide LL-37 and mimics are potential anticancer drugs. Front oncol. 2015;5:144

14. Falla TJ, Karunaratne DN, Hancock REW. Mode of action of the antimicrobial peptide indolicidin. J Biol Chem. 1996;271:19298-303.
15. Ahmad I, Perkins WR, Lupan DM, Selsted ME, Janoff AS. Liposomal entrapment of the neutrophil-derived peptide indolicidin endows it with in vivo antifungal activity. Biochim et Biophys Acta Biomembr. 1995; 1237:109-14.

16. Robinson W, McDougall B, Tran D, Selsted ME. Anti-HIV-1 activity of indolicidin, an antimicrobial peptide from neutrophils. J Leukoc Biol. 1998;63:94-100.

17. Choi KY, Chow LN, Mookherjee N. Cationic host defence peptides: multifaceted role in immune modulation and inflammation. J Innate Immun. 2012;4:361-70

18. Hancock REW, Sahl H-G. Antimicrobial and host-defense peptides as new anti-infective therapeutic strategies. Nat Biotechnol. 2006;24:1551-7.

19. Mansour SC, Pena OM, Hancock RE. Host defense peptides: front-line immunomodulators. Trends Immunol. 2014;35:443-50.

20. Zerfas BL, Gao J. Recent advances in peptide immunomodulators. Curr Top Med Chem. 2015;16:187-205.

21. Nawrocki KL, Crispell EK, McBride SM. Antimicrobial peptide resistance mechanisms of gram-positive bacteria. Antibiotics. 2014;3:461-92.

22. Gunn JS, Lim KB, Krueger J, Kim K, Guo L, Hackett M, Miller SI. PmrAPmrB-regulated genes necessary for 4-aminoarabinose lipid A modification and polymyxin resistance. Mol Microbiol. 1998;27:1171-82.

23. Nizet $\mathrm{V}$. Antimicrobial peptide resistance mechanisms of human bacterial pathogens. Curr Issues Mol Biol. 2006:8:11.

24. Henderson JC, Fage CD, Cannon JR, Brodbelt JS, Keatinge-Clay AT, Trent MS. Antimicrobial peptide resistance of Vibrio cholerae results from an Ips modification pathway related to nonribosomal peptide synthetases. ACS Chem Biol. 2014:9:2382-92.

25. Tran AX, Whittimore JD, Wyrick PB, McGrath SC, Cotter RJ, Trent MS. The lipid A 1-phosphatase of Helicobacter pylori is required for resistance to the antimicrobial peptide polymyxin. J Bacteriol. 2006;188:4531-41.

26. McPhee JB, Bains M, Winsor G, Lewenza S, Kwasnicka A, Brazas MD, Brinkman FSL, Hancock REW. Contribution of the PhoP-PhoQ and PmrA-PmrB two-component regulatory systems to $\mathrm{Mg}^{2+}$-induced gene regulation in Pseudomonas aeruginosa. J Bacteriol. 2006;188:3995-4006.

27. McPhee JB, Lewenza S, Hancock REW. Cationic antimicrobial peptides activate a two-component regulatory system, PmrA-PmrB, that regulates resistance to polymyxin $B$ and cationic antimicrobial peptides in Pseudomonas aeruginosa. Mol Microbiol. 2003;50:205-17.

28. Vaara M. New approaches in peptide antibiotics. Curr Opin Pharmacol. 2009;9:571-6.

29. Schluesener H, Radermacher S, Melms A, Jung S. Leukocytic antimicrobia peptides kill autoimmune T cells. J Neuroimmunol. 1993:47:199-202.

30. de Titta A, Ballester M, Julier Z, Nembrini C, Jeanbart L, van der Vlies AJ, Swartz MA, Hubbell JA. Nanoparticle conjugation of CpG enhances adjuvancy for cellular immunity and memory recall at low dose. Proc Natl Acad Sci USA. 2013;110:19902-7.

31. Wei M, Chen $N$, Li J, Yin M, Liang L, He Y, Song H, Fan C, Huang Q. Polyvalent immunostimulatory nanoagents with self-assembled $\mathrm{CpG}$ oligonucleotide-conjugated gold nanoparticles. Angew Chem Int Ed Engl. 2011;51:1202-6.

32. Ballester M, Nembrini C, Dhar N, de Titta A, de Piano C, Pasquier M, Simeoni E, van der Vlies AJ, McKinney JD, Hubbell JA, Swartz MA. Nanoparticle conjugation and pulmonary delivery enhance the protective efficacy of Ag85B and CpG against tuberculosis. Vaccine. 2011;29:6959-66.

33. Scott MG, Davidson DJ, Gold MR, Bowdish D, Hancock REW. The human antimicrobial peptide LL-37 is a multifunctional modulator of innate immune responses. J Immunol. 2002;169:3883-91.

34. Chen RJ, Zhang Y, Wang D, Dai H. Noncovalent sidewall functionalization of single-walled carbon nanotubes for protein immobilization. J Am Chem Soc 2001:123:3838-9.

35. Adler AH, Schreiber N, Sorkin A, Sorkin S, Wagner G. Visualization of MD and $\mathrm{MC}$ simulation for atomistic modeling. Comput Phys Commun. 2002;147:665-9.

36. Dresselhaus MSD, Avouris G. Carbon nanotubes: synthesis, structure, properties, and applications. Berlin: Springer; 2001

37. Sanders CR. Biomolecular ligand-receptor binding studies: theory, practice, and analysis. Nashville: Vanderbilt University; 2010.

38. Pradhan B, Guha D, Ray P, Das D, Aich P. Comparative analysis of the effects of two probiotic bacterial strains on metabolism and innate immunity in the RAW 264.7 murine macrophage cell line. Probiotics Antimicrob Proteins. 2016:8:73-84. 
39. Awad S, Hassan AN, Muthukumarappan K. Application of exopolysaccharide-producing cultures in reduced-fat Cheddar cheese: texture and melting properties. J Dairy Sci. 2005;88:4204-13.

40. Mookherjee N, Brown KL, Bowdish DME, Doria S, Falsafi R, Hokamp K, Roche FM, Mu R, Doho GH, Pistolic J. Modulation of the TLR-mediated inflammatory response by the endogenous human host defense peptide LL-37. J Immunol. 2006;176:2455-64.

41. Abraham P, George S, Kumar KS. Novel antibacterial peptides from the skin secretion of the Indian bicoloured frog Clinotarsus curtipes. Biochimie. 2014;97:144-51.

42. Tjabringa GS, Ninaber DK, Drijfhout JW, Rabe KF, Hiemstra PS. Human cathelicidin LL-37 is a chemoattractant for eosinophils and neutrophils that acts via formyl-peptide receptors. Int Arch Allergy Immunol. 2006;140:103-12

43. Nijnik A, Pistolic J, Filewod NCJ, Hancock REW. Signaling pathways mediating chemokine induction in keratinocytes by cathelicidin LL-37 and flagellin. J Innate Immun. 2012;4:377-86.

44. Niyonsaba F, Madera L, Afacan N, Okumura K, Ogawa H, Hancock REW. The innate defense regulator peptides IDR-HH2, IDR-1002, and IDR-1018 modulate human neutrophil functions. J Leukoc Biol. 2013:94:159-70.

45. Mantovani A, Cassatella MA, Costantini C, Jaillon S. Neutrophils in the activation and regulation of innate and adaptive immunity. Nat Rev Immunol. 2011;11:519-31.

46. Pena OM, Afacan N, Pistolic J, Chen C, Madera L, Falsafi R, Fjell CD, Hancock REW. Synthetic cationic peptide IDR-1018 modulates human macrophage differentiation. PLOS ONE. 2013;8:e52449.

47. Barlow PG, Beaumont PE, Cosseau C, Mackellar A, Wilkinson TS, Hancock REW, Haslett C, Govan JRW, Simpson AJ, Davidson DJ. The human cathelicidin LL-37 preferentially promotes apoptosis of infected airway epithelium. Am J Respir Cell Mol Biol. 2010;43:692-702.
48. Hu Z, Murakami T, Suzuki K, Tamura H, Kuwahara-Arai K, Iba T, Nagaoka I. Antimicrobial cathelicidin peptide LL-37 inhibits the LPS/ATPinduced pyroptosis of macrophages by dual mechanism. PLoS ONE. 2014;9:e85765.

49. Afacan NJ, Yeung AT, Pena OM, Hancock RE. Therapeutic potential of host defense peptides in antibiotic-resistant infections. Curr Pharm Des. 2012;18:807-19.

50. Mookherjee N, Lippert DND, Hamill P, Falsafi R, Nijnik A, Kindrachuk J, Pistolic J, Gardy J, Miri P, Naseer M. Intracellular receptor for human host defense peptide LL-37 in monocytes. J Immunol. 2009;183:2688-96.

51. Yu J, Mookherjee N, Wee K, Bowdish DME, Pistolic J, Li Y, Rehaume L, Hancock REW. Host defense peptide LL-37, in synergy with inflammatory mediator IL-1 $\hat{\mid}^{2}$, augments immune responses by multiple pathways. J Immunol. 2007;179:7684-91.

52. Van Der Does AM, Joosten SA, Vroomans E, Bogaards SJP, Van Meijgaarden KE, Ottenhoff THM, Van Dissel JT, Nibbering PH. The antimicrobial peptide hLF1-11 drives monocyte-dendritic cell differentiation toward dendritic cells that promote antifungal responses and enhance Th17 polarization. J Innate Immun. 2012;4:284-92.

53. Mookherjee N, Hancock REW. Cationic host defence peptides: innate immune regulatory peptides as a novel approach for treating infections. Cell Mol Life Sci. 2007:64:922-33.

54. Yuk J-M, Shin D-M, Lee H-M, Yang C-S, Jin HS, Kim K-K, Lee Z-W, Lee S-H, Kim J-M, Jo E-K. Vitamin D3 induces autophagy in human monocytes/ macrophages via cathelicidin. Cell Host Microbe. 2009;6:231-43.

55. Niyonsaba F, Ushio H, Nakano N, Ng W, Sayama K, Hashimoto K, Nagaoka I, Okumura K, Ogawa H. Antimicrobial peptides human $\beta$-defensins stimulate epidermal keratinocyte migration, proliferation and production of proinflammatory cytokines and chemokines. J Investig Dermatol. 2007; 127:594-604.

\section{Submit your next manuscript to BioMed Central and we will help you at every step:}

- We accept pre-submission inquiries

- Our selector tool helps you to find the most relevant journal

- We provide round the clock customer support

- Convenient online submission

- Thorough peer review

- Inclusion in PubMed and all major indexing services

- Maximum visibility for your research

Submit your manuscript at www.biomedcentral.com/submit
O Biomed Central 